\title{
CONTRASTING PETROGENETIC ATTRIBUTES OF ASSOCIATED PEGMATITES- APLITES IN IWO AREA, SOUTHWESTERN NIGERIA
}

\author{
Adetunji, A. ${ }^{1 *}$, Olarewaju, V.O. ${ }^{1}$ and Ocan, O.O. ${ }^{2}$ \\ ${ }^{1 *}$ Department of Geology, Obafemi Awolowo University, Ile-Ife, Nigeria \\ ${ }^{2}$ Department of Geological Sciences, Osun State University, Osogbo, Nigeria \\ *Corresponding author: Adetunji, A., aamutiwa@yahoo.co.uk, +234 8025915452 \\ (Received: 5th November, 2017; Accepted: 8th June, 2018)
}

\section{ABSTRACT}

\begin{abstract}
Field, petrographical and geochemical data were used to constrain the petrogenetic attributes of the associated pegmatites and aplites in Iwo area, southwestern Nigeria. The pegmatites and aplites, which occur as veins and dykes are hosted by the $642 \pm 6 \mathrm{Ma}$ quartz potassic syenite. The pegmatites consist of quartz, feldspar with rare biotite and occasional beryl while in addition the aplites contain hornblende instead of biotite and totally lack beryl. Field evidences indicate that the pegmatites are older than the aplites. The two rock varieties show contrasting petrogenetic attributes in their chemical signatures. This is shown by the lack of any correlation or lines of descent in Harker's diagram, non-similarity of the $\mathrm{K} / \mathrm{Rb}$ and $\mathrm{Nb} /$ Ta ratios and the contrasting patterns displayed by some elements in the mantle normalized diagrams (spidergrams) for the associated pegmatites and aplites. The elemental ratios do not support any rare element mineralization potentials for the two rock varieties. The two rock varieties lack significant tetrad effects which indicate crystallization from less evolved magma. This corroborates the negligible $\mathrm{Eu}$ (europium) anomalies for the two rocks (pegmatite: Eu/Eu*=1.02, aplite: $\mathrm{Eu} / \mathrm{Eu}^{*}=1.09$ ). The parental magmas of these rocks though less evolved, displayed contrasting geochemical attributes which indicate different origins. This observation contrasts the general view that associated pegmatite-aplite have a common magma source.
\end{abstract}

Keywords: aplite, pegmatites, Neoproterozoic, magma, Iwo, southwestern Nigeria

\section{INTRODUCTION}

Pegmatites occur throughout the Basement Complex of Nigeria. There are numerous studies on these pegmatites (for example Adetunji et al., 2016; Adetunji and Ocan, 2010; Omada et al., 2015; Okunlola, 2005; Garba, 2002). However, published studies on combined pegmatites and associated aplitesin Nigeria are very rare. According to Jahns and Tuttle (1963), pegmatites and aplites are texturally contrasting rocks but similar compositions and their close spatial relationships imply commonly close genetic affiliations. At thousands of localities throughout the world, they are so intimately associated in both space and time that their derivation from a common magmatic source seems plainly indicated (e.g. Abdelfadil et al., 2016). Moreover, numerous rocks comprise both pegmatitic and aplitic features in various combinations, the paragenetic relationships of which suggest the evolution within what may have amounted to single systems. For example, the mineralized aplite-pegmatite system of Jabal Sayid in the Hijaz region, Kingdom of Saudi Arabia, has been attributed to common descent (Dawood, 2010). Similar petrogenetic attributes had earlier been established for the late Proterozoic Elat-Quarry granite-pegmatite-aplite of southern Israel (Bogoch et al., 1997). This close association, thus, often discourages thought of different origins for such spatially related pegmatite and aplite systems. In this study, field, petrography and geochemistry of the pegmatites and associated aplites in Iwo area, southwest Nigeria have been determined in order to establish whether these rocks have the similar petrogenetic attributes or not. Parts of the data used in this work are from the Ph.D. thesis of the first author (Adetunji, 2012).

\section{GEOLOGICAL SETT'TING}

Iwo area is located in the southern part of the PanAfrican reactivated terrane referred to as the Dahomeyide. The area is bounded to east by the West African Craton, to the southeast by the Congo Craton and northeast by Saharan Metacraton. The regional geology is discussed by several authors among whom are Ajibade and Wright (1989), Ferreet al. (2002), Dada (2006, 1998), Goodenough et al. (2014) and Adetunji et al. (2016, 2018). Locally, the main lithological units in the study area are migmatite-gneiss complex, metasediments and Pan-African granitoids 
(Figure 1). The migmatite-gneiss complex represents the oldest rocks in the Basement Complex of Nigeria. According to Rahaman (1988), it predominantly consists of grey gneiss, granite gneiss, mafic and felsic components, and in some cases relict metasediments. The grey gneiss is made up of biotite and biotite-hornblende varieties of tonalitic to granodioritic composition. Granite gneiss occurs as small pods in the grey gneiss while the mafic components mainly occur as inclusions. The granite gneiss is however mappable in several areas in southwestern Nigeria. Around Ile-Ife in southwestern Nigeria, granite gneiss yielded a U-Pb zircon age of $1.85 \mathrm{Ga}$ (Rahaman, 1988). The felsic components occur as anastomosing veins of aplite, granite and pegmatite. Quartzite (metasediment) forms the major structural markers in the area, particularly with a similar fold at the northeastern end (Figure 1). The axis of the fold has almost north-south orientation that coincides with major foliation in the grey gneiss. The schist is predominantly muscovite-biotite, quartz bearing varieties with amphibolitic type outcropping in few places. In addition to the main minerals, quartz and opaque minerals are prominent. The Pan-African granitoids consist of charnockites, diorites, granites, associated pegmatites and aplites, and quartz potassic syenite. Charnockite occurs as small hills, massive, medium-grained rock. It consists of orthopyroxene, clinopyroxene, hornblende, plagioclase, alkali feldspar, magnetite, quartz and zircon. Diorite occurs in close association with charnockite to west of the syenite. The granite occurs as low lying outcrops, and is of two varieties: biotite and biotitemuscovite types. The quartz potassic syenite outcrops as bosses, low lying and huge discontinuous boulders. It is grey with medium- to coarse-grained texture. The potassic syenite outcrops in an elongated NNE-SSW direction (Rahaman, 1976). The rock is characterized by foliation defined by the parallel alignment in preferred direction of the longer axes of mafic minerals and clots, and K-feldspar. In general, the foliation is well developed at the margin and northern end of the body. The pegmatite and aplite veins studied are all hosted by the syenite. In addition, the syenite is folded at the northern end. Adetunji et al. (2018) give the age of the emplacement and deformation to be $642 \pm 6 \mathrm{Ma}$ which represents an improvement over the $610 \pm$ 7 Ma of Rahaman et al. (1991).

\section{MATERIALS METHODS}

Fourteen whole rock samples comprising seven (7) each of pegmatites and aplites were pulverized and analysed for major, trace and rare earth element (REE) contents at the ACME Laboratories, Vancouver, Canada. Major elements contents were determined with Inductively Coupled Plasma-Atomic Emission Spectrometer (ICP-AES) while trace and REE were analysed with Inductively Coupled Plasma-Mass Spectrometer (ICP-MS). Both equipment were of Perkin Elmer Elan 9000 models. About $0.2 \mathrm{~g}$ each of powdered samples and $1.5 \mathrm{~g}$ lithium borate $\left(\mathrm{LiBO}_{2}\right)$ were heated in a graphite crucible for fifteen minutes at a temperature of $1050{ }^{\circ} \mathrm{C}$. The resulting beads were dissolved in $5 \% \mathrm{HNO}_{3}$. Sample solutions were aspirated into the spectrometers. The detection limits for trace elements range from 0.01 to $0.5 \mathrm{ppm}$ while that of those of the major elements were 0.001 to $0.04 \%$. To ensure reliability of the data, the following standards which were available at the ACME laboratories were used: STD SO-18, STD-DS8, STD-CSC, STD OREAS45PA and STDOREAS76A.

\section{RESULTS}

\section{Petrography of the pegmatites and aplites}

The studied pegmatites occur as small veins with thickness of less than $5 \mathrm{~cm}$ and dykes with a thickness of some meters. A single dyke with discontinuous exposures is traceable for about 7 $\mathrm{km}$ along strike northeast of Iwo. Rahaman (1976) had earlier described a single pegmatite that covers an area of about $25 \mathrm{~km}^{2}$ in Iwo area. Some of the veins in the syenite are folded with fold axes generally parallel to the foliation of the host syenite (Figure 2). This indicates that the folds are synkinematics to the foliation in the syenite. Xenoliths of the pegmatites are present in the associated aplites (Figure 3). Mineralogically, the pegmatites consist of quartz, microcline, trace amount of metallic mineral, occasional traces of biotite and rare beryl. Plagioclase and orthoclase were also recognized in thin sections. 


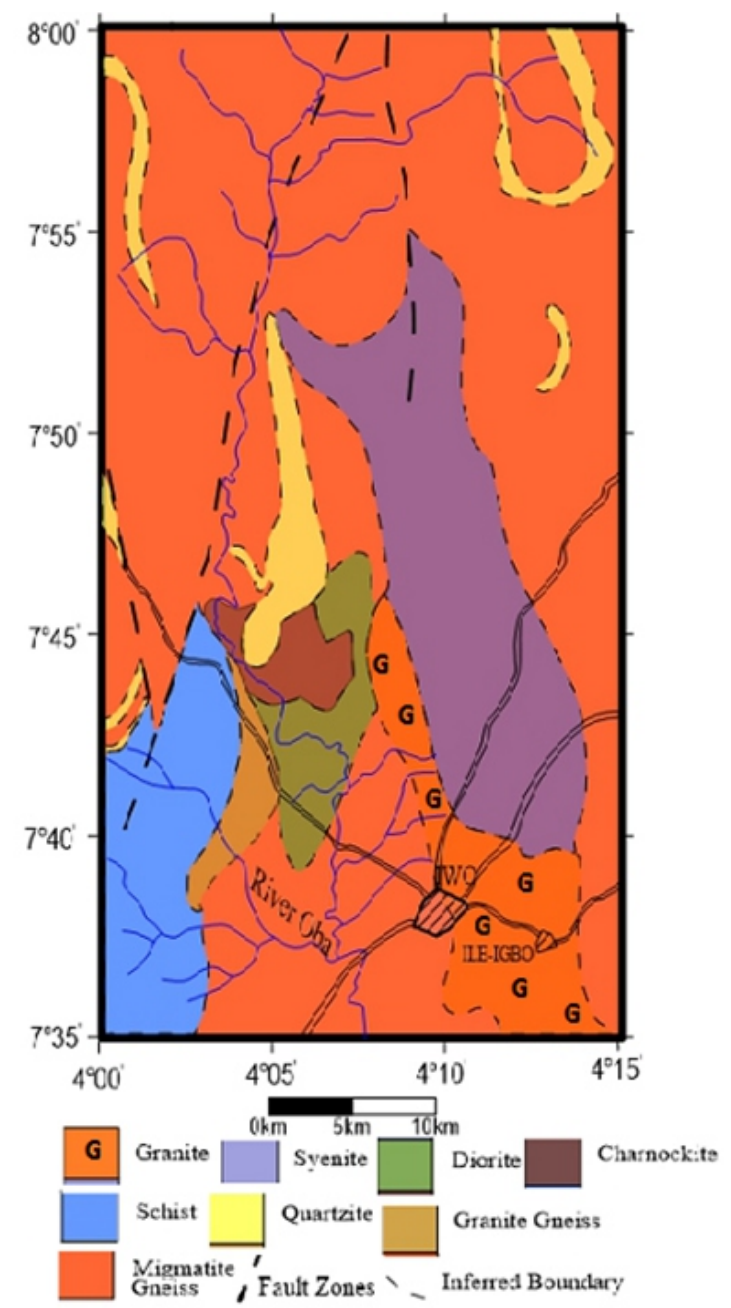

Figure 1: Geological map of Iwo area, southwestern Nigeria (modified from Carter, 1966; Adetunji et al., 2018)

Aplite occurs as small dykes and veins in the study area. It is either associated with the pegmatites or occur as individual bodies in the host syenite (Figure 4). At few places, the aplites contain green spots of hornblende, where these had been

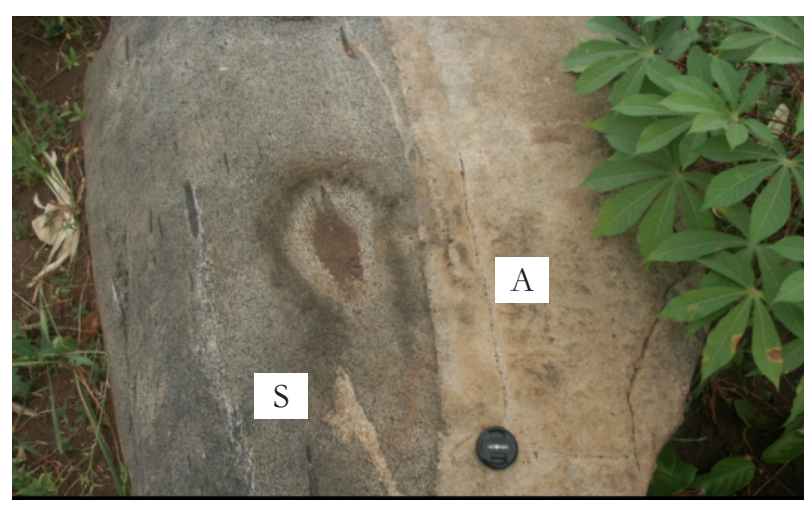

Figure 4: Field photograph of aplite (A) in quartz potassicsyenite $(\mathrm{S})$ in Iwo area.

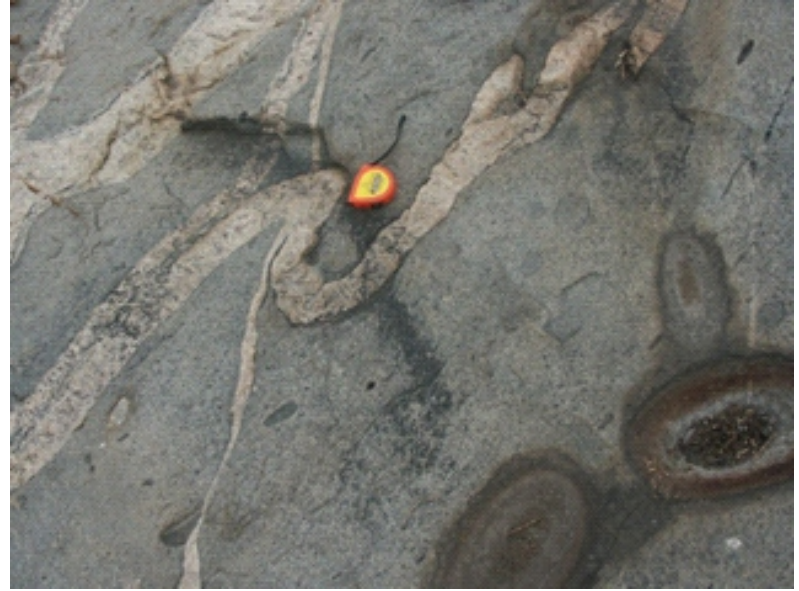

Figure 2: Field photograph showing folded pegmatite veins in quartz potassic syenite.

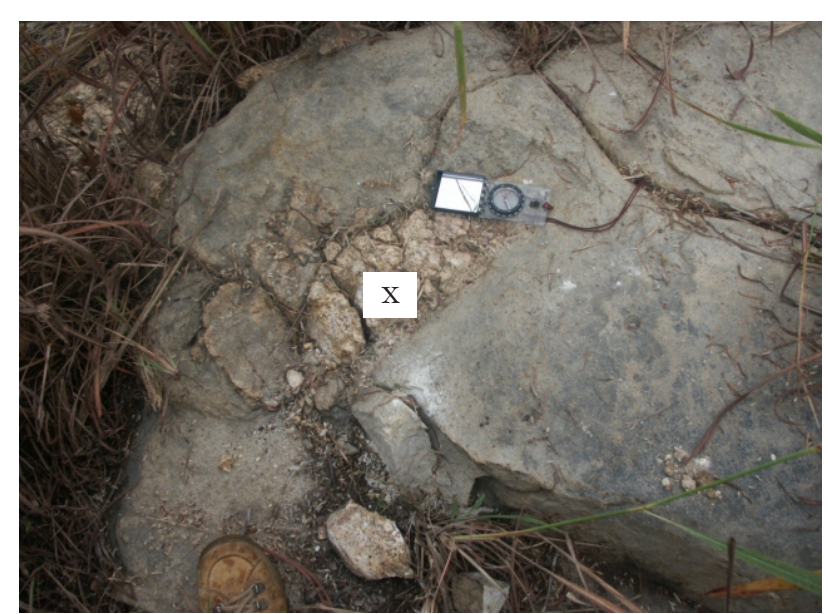

Figure 3: Field photograph showing xenolith of pegmatite $(\mathrm{X})$ in aplite at Iwo Area.

weathered, the spots assume dark brown colouration. Under the microscope, the rock contains quartz, microcline, plagioclase and hornblende (Figure 5).

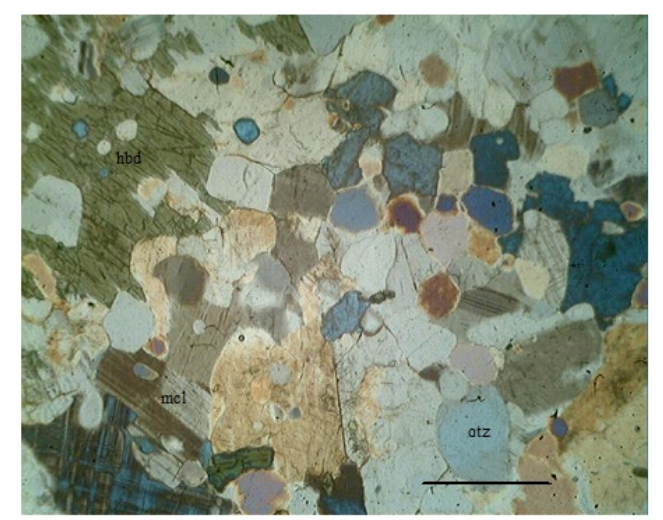

Figure 5: Photomicrograph of aplite showing microcline $(\mathrm{mcl})$, quartz (qtz) and hornblende (hbd) with inclusions of quartz. Bar Scale: $3 \mu \mathrm{m}$ (cross polar). 
Geochemistry of the pegmatites and aplites Seven samples each of pegmatites and aplites were analyzed for major, trace and rare earth elements. The results of these analyses are presented in tables 1 and 2. The Harker diagrams for combined pegmatites and aplites are shown in figures 6 to 9 . The REE chondrite normalized patterns are shown in figures 10 and 11. The REE are normalized to chondritic values of McDonough and Sun (1995). The equivalent mantle normalized spidergrams for the some trace elements are shown in figures 12 and 13 . The values are normalized to that of primordial mantle (McDonough and Sun, 1995).

Table 1: Chemical compositions of the studied pegmatites (oxides in wt. \%, elements in ppm).

\begin{tabular}{|c|c|c|c|c|c|c|c|c|}
\hline Sample & 1 & 2 & 3 & 4 & 5 & 6 & 7 & $\mathrm{n}$ \\
\hline $\mathrm{SiO}_{2}$ & 66.90 & 70.95 & 72.01 & 70.84 & 72.01 & 71.50 & 74.67 & 71.27 \\
\hline $\mathrm{Al}_{2} \mathrm{O}_{3}$ & 17.98 & 15.60 & 14.86 & 15.86 & 15.03 & 15.58 & 13.72 & 15.52 \\
\hline $\mathrm{Fe}_{2} \mathrm{O}_{3}$ & 0.12 & 0.18 & 0.15 & 0.14 & 0.23 & 0.10 & 0.23 & 0.16 \\
\hline $\mathrm{CaO}$ & 0.18 & 0.11 & 0.11 & 0.11 & 0.13 & 0.12 & 0.04 & 0.11 \\
\hline $\mathrm{Na}_{2} \mathrm{O}$ & 2.91 & 3.06 & 2.82 & 3.0 & 2.98 & 3.40 & 3.06 & 3.03 \\
\hline $\mathrm{K}_{2} \mathrm{O}$ & 11.18 & 9.29 & 9.05 & 9.42 & 8.98 & 8.73 & 7.54 & 9.17 \\
\hline $\mathrm{P}_{2} \mathrm{O}_{5}$ & 0.06 & 0.08 & 0.09 & 0.10 & 0.09 & 0.02 & bdl & 0.06 \\
\hline LOI & 0.5 & 0.5 & 0.7 & 0.3 & 0.3 & 0.4 & 0.6 & 0.47 \\
\hline Total & 99.84 & 99.80 & 99.81 & 99.79 & 99.79 & 99.85 & 99.90 & 99.83 \\
\hline $\mathrm{Rb}$ & 535.1 & 401 & 416.1 & 432.9 & 413.4 & 442.6 & 383.3 & 432.06 \\
\hline $\mathrm{Sr}$ & 353.9 & 437.5 & 412.7 & 452.3 & 254.4 & 288.1 & 294.2 & 356.16 \\
\hline Cs & 13.8 & 7.3 & 6.8 & 7.3 & 7.4 & 9.9 & 5.8 & 8.33 \\
\hline $\mathrm{Ba}$ & 1098 & 1408 & 1284 & 1459 & 1371 & 937 & 544 & 1157.29 \\
\hline $\mathrm{Be}$ & 4 & 3 & 3 & 3 & 3 & 2 & 2 & 2.86 \\
\hline $\mathrm{Ga}$ & 24.7 & 23.6 & 23.5 & 25.6 & 24.4 & 21.2 & 20.3 & 23.33 \\
\hline Hf & 0.1 & 0.3 & 0.2 & 0.3 & 0.7 & bdl & 0.2 & 0.26 \\
\hline Sn & 2 & bdl & bdl & bdl & bdl & bdl & 3 & 0.71 \\
\hline $\mathrm{Nb}$ & 1.5 & 1.7 & 2.0 & 2.1 & 1.0 & 0.9 & 5.1 & 2.04 \\
\hline $\mathrm{Ta}$ & 0.7 & 1.1 & 1.2 & 1.6 & 0.9 & 0.5 & 1.4 & 1.06 \\
\hline $\mathrm{Th}$ & 0.6 & bdl & 0.5 & 0.6 & 1.8 & 0.3 & 2.0 & 0.83 \\
\hline $\mathrm{U}$ & 1.1 & 1.4 & 2.0 & 2.0 & 1.4 & 0.3 & 1.5 & 1.39 \\
\hline W & 165.4 & 156.8 & 172.2 & 140.9 & 211.2 & 220.7 & 222.4 & 184.23 \\
\hline $\mathrm{Y}$ & 2.3 & 1.8 & 1.3 & 1.9 & 1.2 & 1.0 & 2.1 & 1.66 \\
\hline $\mathrm{Zn}$ & 1.9 & 2.6 & bdl & bdl & bdl & bdl & Bdl & 0.64 \\
\hline $\mathrm{Zr}$ & 1.9 & 2.6 & 1.5 & 2.9 & 8.6 & 2.2 & 3.4 & 3.30 \\
\hline $\mathrm{K}$ & 92783 & 77098 & 75106 & 78177 & 74525 & 72450 & 62574 & 76102 \\
\hline $\mathrm{K} / \mathrm{Rb}$ & 173 & 192 & 180 & 181 & 180 & 164 & 163 & 176 \\
\hline $\mathrm{Nb} / \mathrm{Ta}$ & 2.1 & 1.5 & 1.7 & 1.3 & 1.1 & 1.8 & 3.6 & 1.87 \\
\hline $\mathrm{La}$ & 2.8 & 4.1 & 4.5 & 8.7 & 4.7 & 2.4 & 2.1 & 4.186 \\
\hline $\mathrm{Ce}$ & 4.0 & 7.5 & 7.6 & 11.3 & 9.2 & 4.8 & 4.8 & 7.029 \\
\hline $\operatorname{Pr}$ & 0.61 & 0.93 & 0.94 & 1.93 & 0.92 & 0.40 & 0.64 & 0.910 \\
\hline $\mathrm{Nd}$ & 2.7 & 4.1 & 3.7 & 7.4 & 3.4 & 1.4 & 2.1 & 3.543 \\
\hline $\mathrm{Sm}$ & 0.48 & 0.71 & 0.59 & 1.23 & 0.63 & 0.28 & 0.58 & 0.643 \\
\hline $\mathrm{Eu}$ & 0.17 & 0.16 & 0.18 & 0.25 & 0.15 & 0.13 & 0.08 & 0.160 \\
\hline $\mathrm{Gd}$ & 0.44 & 0.57 & 0.44 & 0.79 & 0.50 & 0.30 & 0.38 & 0.489 \\
\hline $\mathrm{Tb}$ & 0.06 & 0.06 & 0.05 & 0.08 & 0.05 & 0.03 & 0.06 & 0.056 \\
\hline Dy & 0.38 & 0.34 & 0.35 & 0.45 & 0.25 & 0.25 & 0.45 & 0.353 \\
\hline Ho & 0.06 & 0.04 & 0.04 & 0.05 & 0.03 & 0.02 & 0.07 & 0.044 \\
\hline Er & 0.19 & 0.09 & 0.13 & 0.17 & 0.07 & 0.09 & 0.19 & 0.133 \\
\hline $\operatorname{Tm}$ & 0.03 & 0.01 & bdl & 0.01 & 0.01 & $\mathrm{Bdl}$ & 0.02 & 0.011 \\
\hline $\mathrm{Yb}$ & 0.22 & 0.09 & 0.11 & 0.18 & 0.14 & 0.08 & 0.02 & 0.120 \\
\hline $\mathrm{Lu}$ & 0.02 & bdl & bdl & 0.01 & bdl & bdl & 0.02 & 0.007 \\
\hline $\mathrm{Eu} / \mathrm{Eu}^{*}$ & 1.18 & 0.83 & 1.23 & 0.92 & 0.91 & 1.44 & 0.61 & 1.02 \\
\hline $\mathrm{La}_{\mathrm{n}} / \mathrm{Sm}_{\mathrm{n}}$ & 4 & 3.6 & 4.8 & 4.4 & 4.7 & 5.4 & 2.3 & 4.17 \\
\hline $\mathrm{Ce}_{\mathrm{n}} / \mathrm{Yb}_{\mathrm{n}}$ & 4.8 & 21.9 & 18.2 & 16.5 & 17.2 & 15.7 & 65.3 & 22.8 \\
\hline
\end{tabular}


Table 2: Chemical compositions of the studied aplites (oxides in wt. \%, elements in ppm).

\begin{tabular}{|c|c|c|c|c|c|c|c|c|}
\hline Sample & 1 & 2 & 3 & 4 & 5 & 6 & 7 & $\mathrm{n}$ \\
\hline $\mathrm{SiO}_{2}$ & 71.42 & 71.03 & 70.75 & 72.08 & 70.71 & 71.41 & 70.70 & 71.16 \\
\hline $\mathrm{TiO}_{2}$ & 0.25 & 0.29 & 0.30 & 0.20 & 0.29 & 0.28 & 0.30 & 0.27 \\
\hline $\mathrm{Al}_{2} \mathrm{O}_{3}$ & 14.83 & 15.55 & 15.50 & 15.13 & 15.26 & 14.90 & 15.45 & 15.23 \\
\hline $\mathrm{Fe}_{2} \mathrm{O}_{3}$ & 1.35 & 1.74 & 1.69 & 1.40 & 1.57 & 1.41 & 1.68 & 1.55 \\
\hline $\mathrm{MnO}$ & 0.02 & 0.05 & 0.04 & 0.02 & 0.04 & 0.3 & 0.04 & 0.07 \\
\hline $\mathrm{MgO}$ & 0.27 & 0.34 & 0.41 & 0.11 & 0.30 & 0.28 & 0.40 & 0.30 \\
\hline $\mathrm{CaO}$ & 1.37 & 1.29 & 1.34 & 1.07 & 1.25 & 1.36 & 1.33 & 1.29 \\
\hline $\mathrm{Na}_{2} \mathrm{O}$ & 5.17 & 6.84 & 5.66 & 5.84 & 5.92 & 5.25 & 5.73 & 5.77 \\
\hline $\mathrm{K}_{2} \mathrm{O}$ & 4.49 & 2.18 & 3.59 & 3.33 & 4.04 & 4.21 & 3.60 & 3.63 \\
\hline $\mathrm{P}_{2} \mathrm{O}_{5}$ & 0.12 & 0.10 & 0.10 & 0.10 & 0.08 & 0.09 & 0.11 & 0.10 \\
\hline LOI & 0.4 & 0.4 & 0.4 & 0.5 & 0.3 & 0.4 & 0.3 & 0.39 \\
\hline $\mathrm{Rb}$ & 197.4 & 86 & 149.8 & 135.6 & 198.3 & 198.2 & 147.4 & 158.96 \\
\hline $\mathrm{Sr}$ & 381.4 & 427.6 & 311.5 & 438.0 & 321.0 & 383.2 & 426.5 & 384.17 \\
\hline Cs & 3.0 & 1.9 & 2.7 & 3.6 & 4.5 & 3.2 & 2.9 & 3.11 \\
\hline $\mathrm{Ba}$ & 1553 & 717 & 686 & 1059 & 1125 & 1531 & 696 & 1052.43 \\
\hline $\mathrm{Be}$ & 11 & 8 & 17 & 4 & 4 & 9 & 10 & 9.00 \\
\hline $\mathrm{Ga}$ & 24.6 & 23.8 & 22.7 & 24.5 & 17.9 & 23.8 & 22.9 & 22.89 \\
\hline $\mathrm{Hf}$ & 4.2 & 5.3 & 6.0 & 4.1 & 5.9 & 4.5 & 5.4 & 5.06 \\
\hline $\mathrm{Sn}$ & 8 & 4 & 27 & 3 & 4 & 6 & 5 & 8.14 \\
\hline $\mathrm{Nb}$ & 14.7 & 10.5 & 33.5 & 10.3 & 10.6 & 13.4 & 10.6 & 14.80 \\
\hline $\mathrm{Ta}$ & 3.1 & 1.3 & 6.0 & 1.4 & 1.3 & 2.8 & 1.7 & 2.51 \\
\hline Th & 13.3 & 19.3 & 34.9 & 13.4 & 33.8 & 13.4 & 31.2 & 22.76 \\
\hline $\mathrm{U}$ & 2.9 & 3.1 & 10.0 & 3.4 & 4.8 & 2.8 & 7.3 & 4.90 \\
\hline W & 254.4 & 301.3 & 170.0 & 163.0 & 239.6 & 257.2 & 173.4 & 222.70 \\
\hline Y & 5.4 & 5.5 & 10.4 & 6.8 & 7.0 & 5.6 & 5.8 & 6.64 \\
\hline $\mathrm{Zn}$ & 29 & 34 & 18 & 32 & 31 & 27 & 30 & 28.71 \\
\hline $\mathrm{Zr}$ & 165.0 & 173.6 & 197.8 & 145.9 & 199.5 & 143.3 & 197.2 & 174.61 \\
\hline $\mathrm{K}$ & 37274 & 18097 & 29803 & 27644 & 33538 & 34950 & 29886 & 30170.2 \\
\hline $\mathrm{K} / \mathrm{Rb}$ & 189 & 210 & 199 & 204 & 169 & 176 & 203 & 193 \\
\hline $\mathrm{Nb} / \mathrm{Ta}$ & 5 & 8 & 6 & 7 & 8 & 5 & 6 & 6.43 \\
\hline $\mathrm{La}$ & 36.4 & 29.8 & 52.5 & 28.9 & 48.0 & 37.1 & 51.3 & 40.57 \\
\hline $\mathrm{Ce}$ & 66.8 & 81.9 & 105.4 & 52.0 & 117.9 & 68.1 & 103.4 & 85.07 \\
\hline $\operatorname{Pr}$ & 6.67 & 6.38 & 10.08 & 6.03 & 10.16 & 6.82 & 6.68 & 7.55 \\
\hline $\mathrm{Nd}$ & 21.6 & 22.5 & 31.7 & 21.9 & 33.2 & 21.7 & 29.5 & 26.01 \\
\hline $\mathrm{Sm}$ & 2.97 & 3.13 & 4.38 & 3.24 & 4.69 & 2.98 & 3.67 & 3.58 \\
\hline $\mathrm{Eu}$ & 0.71 & 0.76 & 0.78 & 0.82 & 0.93 & 0.72 & 0.77 & 0.78 \\
\hline Gd & 1.79 & 1.94 & 2.88 & 2.24 & 2.62 & 1.81 & 2.86 & 2.31 \\
\hline $\mathrm{Tb}$ & 0.22 & 0.24 & 0.43 & 0.28 & 0.32 & 0.23 & 0.23 & 0.28 \\
\hline Dy & 0.93 & 1.09 & 2.06 & 1.12 & 1.37 & 0.94 & 1.47 & 1.28 \\
\hline Ho & 0.14 & 0.15 & 0.34 & 0.21 & 0.21 & 0.15 & 0.23 & 0.20 \\
\hline Er & 0.38 & 0.41 & 0.95 & 0.51 & 0.54 & 0.39 & 0.94 & 0.59 \\
\hline $\mathrm{Tm}$ & 0.06 & 0.06 & 0.16 & 0.08 & 0.08 & 0.07 & 0.08 & 0.08 \\
\hline $\mathrm{Yb}$ & 0.34 & 0.36 & 1.02 & 0.41 & 0.47 & 0.35 & 0.42 & 0.48 \\
\hline $\mathrm{Lu}$ & 0.05 & 0.06 & 0.15 & 0.07 & 0.07 & 0.06 & 0.07 & 0.08 \\
\hline $\mathrm{Eu} / \mathrm{Eu}^{*}$ & 1.14 & 1.17 & 1.16 & 1.12 & 1.0 & 1.16 & 0.89 & 1.09 \\
\hline $\mathrm{La}_{\mathrm{n}} / \mathrm{Sm}_{\mathrm{n}}$ & 8 & 6 & 7 & 6 & 6 & 8 & 9 & 7.14 \\
\hline $\mathrm{Ce}_{\mathrm{n}} / \mathrm{Yb}_{\mathrm{n}}$ & 51.6 & 63.3 & 27.1 & 33.3 & 65.9 & 51.2 & 64.6 & 51 \\
\hline
\end{tabular}

bdl: Below Detection Limit, LOI: Loss On Ignition, n: Average Composition 


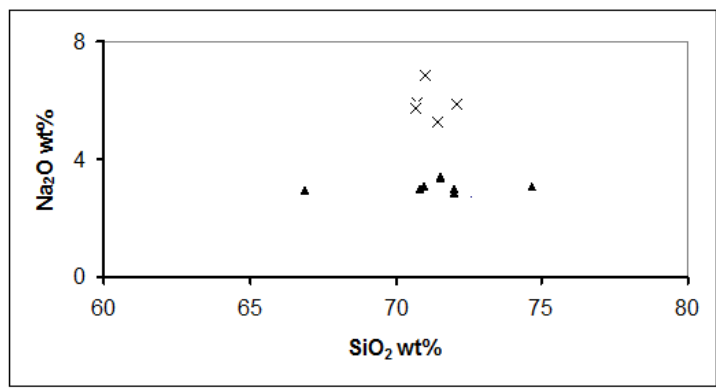

Figure 6: Plot of $\mathrm{SiO}_{2}$ vs. $\mathrm{Na}_{2} \mathrm{O}$ for the pegmatites and aplites. $\boldsymbol{\Lambda}$ : pegmatites, $\mathrm{X}$ : aplites

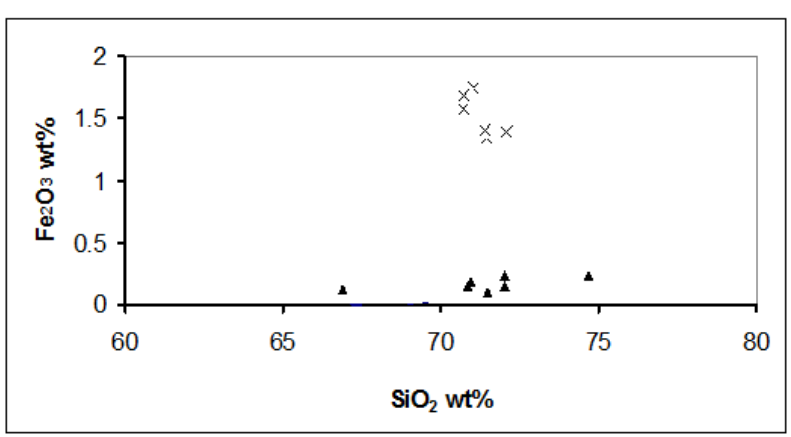

Figure 8: Plot of $\mathrm{SiO}_{2}$ vs. $\mathrm{Fe}_{2} \mathrm{O}_{3}$ for the pegmatites and aplites. Symbols as defined in figure 6 .

As shown in table 1, the pegmatites are characterized by high values of $\mathrm{SiO}_{2}$ (66.9 to 74.67 wt. $\%$ ) with an average of 71.27 wt. $\%$; high $\mathrm{Al}_{2} \mathrm{O}_{3}$ $(13.72$ to 17.98 wt. $\%)$ with an average of $15.52 \mathrm{wt}$. $\%$; low $\mathrm{Fe}_{2} \mathrm{O}_{3}(0.1$ to 0.23 wt. $\%)$ with an average of 0.16 wt. $\%$. The values of $\mathrm{MnO}, \mathrm{MgO}, \mathrm{Cr}_{2} \mathrm{O}_{3}$ and $\mathrm{TiO}_{2}$ are below detection limits. The rock generally has a low $\mathrm{CaO}$ ranging from 0.04 to 0.18 wt. $\%$ with an average of 0.11 wt. $\%$, moderate $\mathrm{Na}_{2} \mathrm{O}(2.82$ to 3.4 wt. \%) with an average of 3.03 wt. $\%$. The $\mathrm{K}_{2} \mathrm{O}$ values are high ranging from 7.54 to 11.18 wt. $\%$ with an average of 9.17 wt. $\%$. The values of $\mathrm{P}_{2} \mathrm{O}_{5}$ are generally low, ranging from 0.02 to 0.1 wt. $\%$ with an average of 0.06 wt. $\%$. The aluminum saturation index (ASI) 0.83 indicates that the pegmatites are slightly metaluminous. This ASI was calculated from the expression: $\mathrm{Al} /(\mathrm{Ca}-1.67 \mathrm{P}+\mathrm{Na}+\mathrm{K})$ (Frost et al., 2001).

As shown in table 2, the aplites are characterized by high values of $\mathrm{SiO}_{2}(70.70$ to 72.08 wt. \%) with an average of 71.16 wt. $\%$; low $\mathrm{TiO}_{2}(0.2$ to 0.3 wt. $\%$ ) with an average of 0.27 wt. $\%$; high $\mathrm{Al}_{2} \mathrm{O}_{3}$ (14.83 to 15.55 wt. $\%$ ) with an average of $15.23 \mathrm{wt}$. $\%$; moderate $\mathrm{Fe}_{2} \mathrm{O}_{3}(1.35$ to 1.74 wt. \%) with an average of 1.55 wt. $\%$. The concentrations of

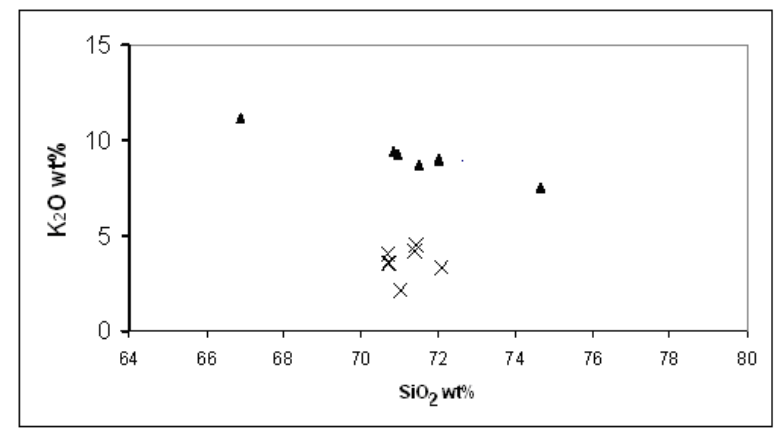

Figure 7: Plot of $\mathrm{SiO}_{2}$ vs. $\mathrm{K}_{2} \mathrm{O}$ for the pegmatites and aplites. Symbols as defined in figure 6.

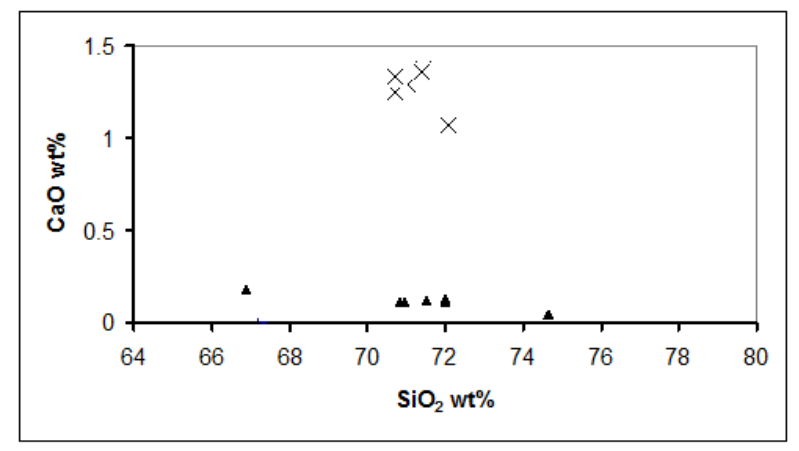

Figure 9: Plot of $\mathrm{SiO}_{2}$ vs. $\mathrm{CaO}$ for the pegmatites and aplites.Symbols as defined in figure 6 .

$\mathrm{MnO}$ and $\mathrm{MgO}$ range from 0.02 to 0.3 wt. $\%$ with an average of 0.07 wt. $\%$ and 0.11 to 0.41 wt. $\%$ with an average of 0.3 wt. $\%$, respectively. The rock generally has a uniformly low $\mathrm{CaO}$ ranging from 1.07 to $1.37 \mathrm{wt} . \%$ with an average of $1.29 \mathrm{wt}$. $\%$, moderate $\mathrm{Na}_{2} \mathrm{O}$ (5.17 to 6.84 wt. \%) with an average of 5.77 wt. \%. The concentrations of $\mathrm{K}_{2} \mathrm{O}$ range from 2.18 to 4.49 wt. \% with an average of 3.63 wt. $\%$ while $\mathrm{P}_{2} \mathrm{O}_{5}$ is low ranging from 0.09 to 0.12 wt. $\%$ with an average of 0.10 wt. $\%$. The concentration of $\mathrm{Cr}_{2} \mathrm{O}_{3}$ is below detection limit. The aluminum saturation index (ASI) of 1.10 indicates that the pegmatite is peraluminous. This ASI was calculated from the expression $\mathrm{Al} /(\mathrm{Ca}-$ 1.67P+Na+K) (Frost et al., 2001).

The pegmatites have higher average values of $\mathrm{Rb}$, $\mathrm{Cs}, \mathrm{Ba}$ and $\mathrm{Ga}$ than the aplite while the aplites have higher mean values of $\mathrm{Sr}, \mathrm{Be}, \mathrm{Hf}, \mathrm{Sn}, \mathrm{Nb}, \mathrm{Ta}$, Th, $\mathrm{U}, \mathrm{W}, \mathrm{Y}, \mathrm{Zn}, \mathrm{Zr}, \mathrm{K} / \mathrm{Rb}$ and $\mathrm{Nb} / \mathrm{Ta}$. The values of REE are generally low for the two rock varieties. There is depletion of both HREE and LREE. The two rock varieties have statistically similar $\mathrm{Eu}$ (europium) anomalies (Eu/Eu*). Eu* is the value obtained at the europium position by a straight line interpolation between the plotted points for 
$\mathrm{Sm}_{\mathrm{n}}$ and $\mathrm{Gd}_{\mathrm{n}}$. The chemical data of the pegmatites and aplitesare plotted on different variation diagrams. The distribution of the data and some elemental ratios allow deductions to be made about the sources of pegmatitic melts, extent of fractionation, chemical characterization and their mineralization potentials. Selected major elements are plotted on Harker diagrams using $\mathrm{SiO}_{2}$ as differentiation index (Figures 6 to 9). In the plot of $\mathrm{SiO}_{2} \mathrm{vs} . \mathrm{Na}_{2} \mathrm{O}$ (Figure 6), there is nodiscernible pattern display by the two rock types. This probably indicates crystallization from unrelated magmas. The plot of $\mathrm{SiO}_{2}$ vs. $\mathrm{K}_{2} \mathrm{O}$ (Figure7) showsdistinct fields for the rock varieties, however, pegmatite data show negative correlation. Equally, the plots of $\mathrm{SiO}_{2}$ vs. $\mathrm{Fe}_{2} \mathrm{O}_{3}$ and $\mathrm{CaO}$ (Figures 8 and 9) separate the two rock varieties into two distinct fields with no connecting line of descent. This apparently suggests crystallization from magmas of different sources (Wilson, 1989). The scattered data points among each rock variety may indicate contamination of the pegmatitic melts.
The $\mathrm{K} / \mathrm{Rb}$ and $\mathrm{Nb} / \mathrm{Ta}$ ratios of the pegmatites range from 163 to 192 with an average of 176; and 1.1 to 3.6 with an average of 1.87 , respectively (Table. 1). This high $\mathrm{K} / \mathrm{Rb}$ ratio could be ascribed to non-fractionation of the pegmatites, this rules out any rare element mineralization potential. The values of REE are generally low. There is a general depletion of both HREE and LREE in the pegmatites but with HREE more depleted than the LREE (Table 1). The chondrite normalized REE diagrams show similar patterns with uniform slope (Figure 10). There segmentation of chondrite normalized REE pattern into four sectors (tetrad effects) is not pronounced as shown in Fig. 10. There is negligible europium anomaly $\left(\mathrm{Eu} / \mathrm{Eu}^{*}=1.02\right)$. $\mathrm{Eu}^{*}$ is the value obtained at the europium position by a straight line interpolation between the plotted points for $\mathrm{Sm}_{\mathrm{n}}$ and $\mathrm{Gd}_{\mathrm{n}}$. The high means of $\mathrm{La}_{\mathrm{n}} / \mathrm{Sm}_{\mathrm{n}}(4.17)$ and $\mathrm{Ce}_{\mathrm{n}} / \mathrm{Yb}_{\mathrm{n}}(22.8)$ ratios indicate that there is slight fractionation of LREE and HREE. The spidergram (Figure 12) shows major troughs at $\mathrm{Zr}, \mathrm{Nb}$ and $\mathrm{Th}$ with peaks at $\mathrm{Rb}, \mathrm{U}, \mathrm{K}$ and Sr.

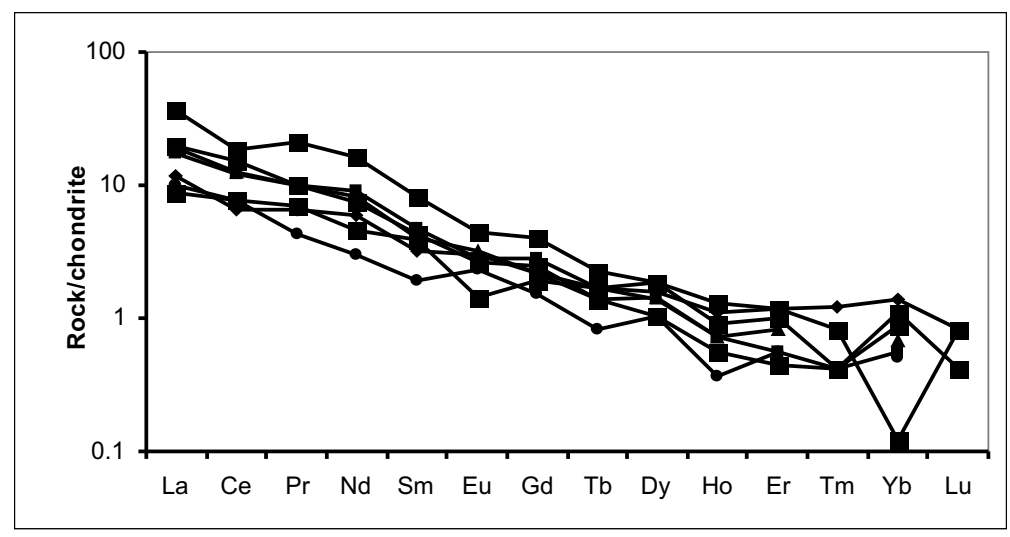

Figure 10: Chondrite normalized REE pattern for pegmatites in the study area.

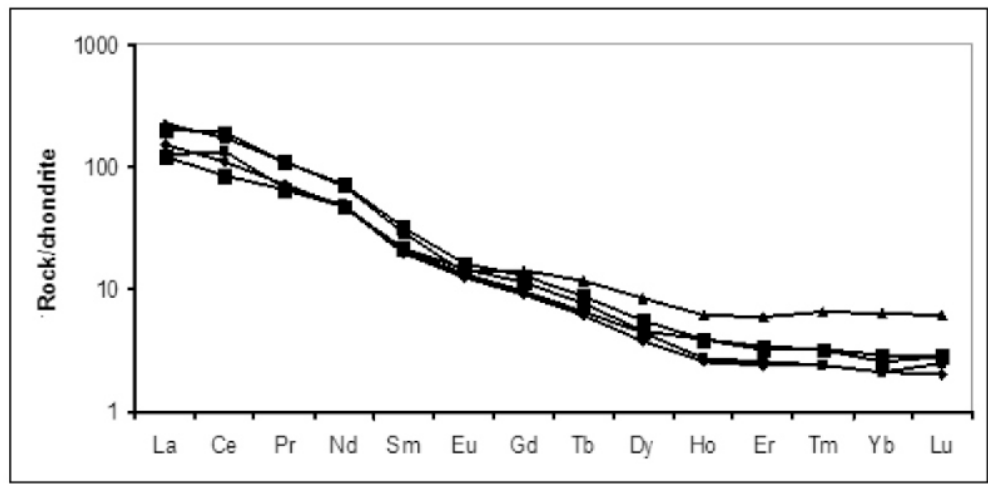

Figure 11: Chondrite normalized REE patterns for aplites in the study area. 


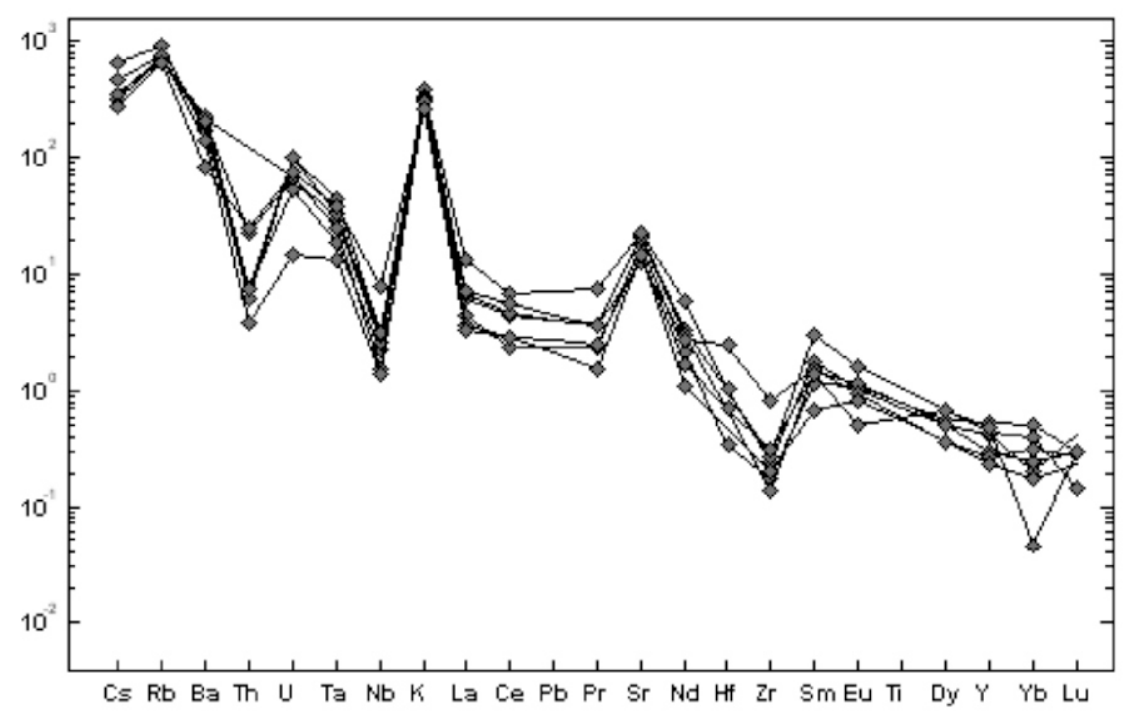

Figure 12: Spidergram for pegmatites in the study area. Values are normalized to that of primordial mantle (McDonough and Sun, 1995).

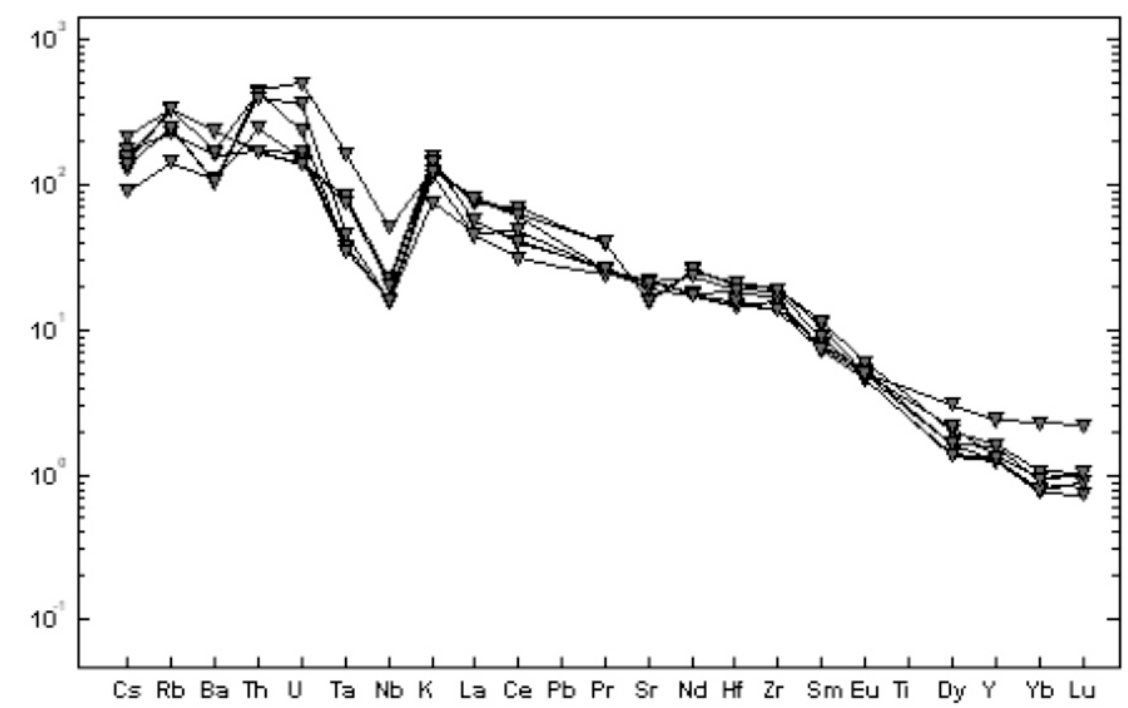

Fig. 13 Spidergram for aplites in the study area. Values are normalized to that of primordial mantle (McDonough and Sun, 1995).

Also, the $\mathrm{K} / \mathrm{Rb}$ ratios for the aplites range from 169 to 203 with an average of 193 and $\mathrm{Nb} / \mathrm{Ta}$ ranges from 5 to 8 with an average of 6.5 (Table 2). The high ratios of these indicators point to low degree of fractionation. The values of REE are generally low, but the LREE are more enriched than HREE. The REE chondrite normalized diagrams show the same pattern and display a slight europium depletion (Figure 11) with slight positive europium anomaly $\left(\mathrm{Eu} / \mathrm{Eu}^{*}=1.09\right)$. Eu* is the value obtained at the europium position by a straight line interpolation between the plotted points for $\mathrm{Sm}_{\mathrm{n}}$ and $\mathrm{Gd}_{\mathrm{n}}$. The aplites display weak tetrad effects in the chondrite normalized pattern.
Equally, the LREE show steeper slopes while the HREE have almost flat plateau at the (fourth) last REE sector (Figure 11). The high $\mathrm{La}_{\mathrm{n}} / \mathrm{Sm}_{\mathrm{n}}$ and $\mathrm{Ce}_{\mathrm{n}} / \mathrm{Yb}_{\mathrm{n}}$ ratios are further indicators of the low fractionation of the REE in the aplites. The spidergram (Figure 13) shows major troughs at $\mathrm{Ba}$, $\mathrm{Nb}$ and $\mathrm{Sr}$ with prominent peaks at Rb, Th, U and $\mathrm{K}$.

\section{DISCUSSIONAND CONCLUSION}

Diversity of rocks of pegmatite suite (pegmatite and aplite inclusively) from common origin can be explained by either fluid/melt or liquid/liquid mechanisms (London, 2005; Thomas and Veksler, 
2002; Thomas and Davidson, 2007). Pegmatites that evolved dominantly from fluid/melt mechanism often show strong Eu depletion and tetrad effects which is displayed in the chondrite normalized patterns as segmentation into four sectors (Zhao et al., 2002). These characteristics are not shown in both the pegmatites and aplites of Iwo area. The lack of these attributes is indicative of crystallization from relatively poorly fractionated magmas (Zhao et al., 2002). The high $\mathrm{K} / \mathrm{Rb}$ ratios for both the pegmatites and aplites are consistent with these observations. So, the large differences in $\mathrm{La}_{\mathrm{n}} / \mathrm{Sm}_{\mathrm{n}}$ for pegmatites (4.17) and aplites (7.14) and $\mathrm{Ce}_{\mathrm{n}} / \mathrm{Yb}_{\mathrm{n}}$ (pegmatite: 22.8, aplite: 51) are not due to fractionation but crystallization from different origins. Igneous suites of common origin plots linearly with either positive or negative correlation in the Harker diagram (Wilson, 1989). Where such rocks have evolved through fractional crystallization, lines of descent are shown on such Harker diagram. There are no such correlation and lines of descent for the Iwo pegmatites and aplites (Figure 6 to 9).Titanium which is below detection limit in the pegmatites but with a mean value of 0.29 wt. $\%$ in the aplites indicates that the aplitic melt was rich in Ti. The Ti in the aplites could not have been due to contamination from the host syenite because such contamination did not affect pegmatites that occur together with the aplites. These chemical signatures do not support a common line of descent for both pegmatites and aplites. Also, field relationships indicate that the emplacement of pegmatites predates that of aplites, yet $\mathrm{MgO}$ is detected in the younger aplites but below detection limit in the older pegmatites. This also supports different magmatic origins for the two rock varieties.

The pegmatites have major troughs at $\mathrm{Ba}, \mathrm{Zr}, \mathrm{Nb}$ and Th; and peaks at Rb, U, K and Sr in the mantle normalized pattern (Figure 12). This is in sharp contradiction with aplites which show slight troughs at $\mathrm{Ba}, \mathrm{Nb}$ and $\mathrm{Sr}$; absence of trough at $\mathrm{Zr}$ and peak at $S r$. These are consistent with rocks of different origins. The $\mathrm{K} / \mathrm{Rb}$ ratios for the two rock varieties are well above 100 which has been suggested to be the upper limit for mineralized pegmatites (Cerny and Burt, 1984; Cerny, 1991). In conclusion, association of pegmatite and aplite in the field does not necessarily indicate rocks that crystallized from cogenetic magma. Geochemistry rather than field association gives a reliable tool to discriminate genetic relationships between associated pegmatites and aplites.

\section{REFERENCES}

Abdelfadili, K.M., Asimow, P.D., Azer, M.K. and Gahlan, H.A. 2016. Genesis and petrology of Late Neoproterozoic pegmatites and aplites associated with the Taba metamorphic complex in southern Sinai, Egypt. Geologica Acta 14 (3): 219-235.

Adetunji, A. 2012. Geochemical and petrogenetic studies of pegmatites in some parts of Osun State, southwestern Nigeria. Unpublished $\mathrm{PhD}$ thesis, Obafemi Awolowo University, Ile-Ife, Nigeria. 256 pp.

Adetunji, A. and Ocan, O.O. 2010. Characterization and mineralization potentials of pegmatites of Komu area, southwestern Nigeria. Resource Geology 60 (1): 87-97.

Adetunji, A., Olarewaju, V.O., Ocan, O.O., Ganev, V.Y. and Macheva, L. 2016. Geochemistry and $\mathrm{U}-\mathrm{Pb}$ zircon geochronology of the pegmatites in Ede area, southwestern Nigeria: A newly discovered oldest PanAfrican rock in southwestern Nigeria. Journal of African Earth Sciences 115, 177190.

Adetunji, A., Olarewaju, V.O., Ocan, O.O., Ganev, V.Y. and Macheva, L. 2018. Geochemistry and U-Pb zircon geochronology of Iwo quartz potassic syenite, southwestern Nigeria: Constraints on petrogenesis, timing of deformation and terrane amalgamation. Precambrian Research 307: 125-136.

Ajibade, A.C. and Wright, J.B. 1989.'The Togo Benin Nigeria shield: evidence of crustalaggregation in the Pan-African belt. Tectonophysics 165: 125-129.

Bogoch, R., Bourne. J, Shirav, M. and Harnois, L. 1997.Petrochemistry of a late Precambrian garnetiferous granite, pegmatite and aplite, southern Israel. Mineralogical Magazine 61:111-122.

Carter, J.D. 1966. Geological Survey Nigeria. Bulletin 38.

Cerny, P. 1991. Rare element granitic pegmatites: 
anatomy and internal evolution of pegmatite deposits. Geoscience Canada 11: 30-47.

Cerny, P. and Burt, D.M. 1984. Paragenesis, crystallochemical characteristics and geochemical evolution of micas in graniticpegmatites. In: Micas, S.W., Baily (editor), Review in Mineralogy 13: 257-297.

Dada, S.S. 1998.Crust-forming ages and Proterozoic crustal evolution in Nigeria: a reappraisal of current interpretations. Precambrian Research 87: 65-74.

Dada, S.S. 2006. Proterozoic evolution of Nigeria. In: The Basement Complex of Nigeria and its mineral resources, Oshin, O. (editor), A Tribute to Prof RahamanM A O, Akin Jinad\& Co Ibadan pp. 29-44.

Dawood, Y.H., Harbia, H.M. andAbd el-Nabya, H.H. 2010. Genesis of kasoliteassociated withaplite-pegmatite at JabalSayid, Hijaz region, Kingdom of Saudi Arabia. Journal of Asian EarthSciences 37 (1): 1-9.

Ferre, E.C., Gleizes, G. andCaby, R. 2002. Obliquely convergent tectonics and Granite emplacement in the TransSaharan belt of Eastern Nigeria: a synthesis. Precambrian Research 114: 199219.

Frost, B.R., Barnes, C.G., Collins, W.J., Arculus, R.J., Ellis, D.J.and Frost, C.D. 2001. A Geochemical classification for granitic rocks. Journal of Petrology 42 (11): 20332048.

Garba, I. 2002. Late Pan-African tectonics and origin of Au mineralization and rare metal pegmatites in Kushaka Schist Belt, northwestern Nigeria. Nigerian Journal of Mining and Geology 38(1): 1-12.

Goodenough, K.M., Lusty, P.A.J., Roberts, N.M.W., Key, R.M. and Garba, A. 2014. Post-collisional Pan-African granitoids and rare metal pegmatites in western Nigeria: Age, petrogenesis, and the pegmatite conundrum. Lithos 200-201:2234.

Jahns, R.H. and Turtle, O.F. 1963. Layered pegmatite-apliteintrusives. Mineralogical Society of America specialpaper 1:78-92.

London, D. 2005. Granitic pegmatites: an assessment of current concepts and directions for future.

Lithos 80: 281-303.

McDonough, W.F. and Sun, S.S. 1995. The composition of the Earth. Chemical Geology 120, 223-253.

Okunlola, O. A. 2005.Metallogeny of $\mathrm{Ta}-\mathrm{Nb}$ mineralization of Precambrian pegmatites of Nigeria. Mineral $W$ e a $l t h$ 137: 38-50.

Omada, J.I., Kolawole, M.S. and Odoma, A.N. 2015. Field and petrochemical studies of pegmatites in parts of Lokoja, central Nigeria. Journal of African Earth Sciences 101: 266-273.

Rahaman, M.A. 1976. Review of the basement geology of southwestern Nigeria. In: Geology of Nigeria, Kogbe, C.A. (editor), Elizabethan Pub. Co. Lagos pp. 41-58.

Rahaman, M.A. 1988. Recent advances in the study of the Basement Complex of Nigeria. In:

Precambrian Geology of Nigeria, Oluyide, P.O., Mbonu, W.C.,Ogezi, A.E., Egbuniwe, I.G., Ajibade, A.C. and Umeji, A.C. (editors), Geological Survey of Nigeria spec. pub. pp. 11-41.

Thomas, R. and Davidson, P. 2007. The formation of granitic pegmatites from the view point ofmelt and fluid inclusions and new experimental work. The state of art symposium on granitic pegmatites 6th - 12th May, 2007, Portal, Portugal, 4 pp.

Thomas, R. and Veksler, I. 2002. Formation of granitic pegmatites in the light of melt and fluid inclusion studies and new and old experimental work. Polskie Towarsystwo Mineralogiczne-Prace Specjalne. Mineralogical Society of Poland Special Papers Zeszyt 20: $44-49$.

Wilson, M. 1989.Igneous Petrogenesis. Unwin Hyman Inc London, $466 \mathrm{pp}$.

Zhao, Z.H.,Xiong, X., Han, X., Wang, Y., Wang, Q., Bao, Z. and Borming, J. 2002. Controls on the REE tetrad effect in granite: Evidence from the Qianlishan and Baerzhe granites,China. Geochemical Journal36: 527-543. 